\title{
Analysis of Determinants of Migrant Labor in Developing Countries in Asia Pacific
}

\author{
$\mathrm{Adib}^{1 *}$, Idris $^{2}$ \\ 1, 2 Universitas Negeri Padang, Padang, Indonesia \\ *Corresponding author. Email: Tanjungadib@gmail.com
}

\begin{abstract}
This study aims to determine and analyze the influence of the relationship between Economic Growth, Unemployment, FDI and the Human Development Index on Migrant Workers in 10 developing countries in Asia Pacific during the period 2010-2018. This type of research is descriptive and associative. The type of data used is secondary data. This study uses a Random Effect Model (REM) approach.

The results of this study indicate that: (1) Based on the results of the research conducted, it shows that Economic Growth (X1) has a positive and significant effect on Migrant Workers (Y) in 10 developing countries in Asia Pacific. (2) Based on the results of the equation research shows that unemployment (X2) has a positive effect on Migrant Workers (Y) in 10 developing countries in Asia Pacific. (3) Based on the results of the equation research, FDI (X3) has a positive effect on Migrant Workers (Y) in 10 developing countries in Asia Pacific. (4) Based on the results of the equation research, the Human Development Index (X4) has a positive effect on Migrant Workers (Y) 10 developing countries in Asia Pacific
\end{abstract}

Keywords: Migrant workers, Economic growth, Unemployment, FDI, Human development index.

\section{INTRODUCTION}

Migration is a global and growing phenomenon. Migration consists of many types of movements: to work, for family reasons, for studying, or for forced migration as a result of conflict or natural disasters. In the World, international migration is most often about finding work, although movements of all kinds can be found. this research focuses on labor migration in Asia and by Asians around the world (ILO 2016).

Over the centuries, people have migrated in search of opportunities for economic prosperity or political freedom. Over the past two decades, international migration has developed rapidly, mainly due to the globalization of economic activity and the subsequent impact on labor migration [1].

Changes in the economic structure of the agricultural sector to the industrial sector have long been considered as one of the factors causing the entry of foreign workers into a country's labor market so that a country can no longer prevent foreign workers from working in its country. So that being a migrant worker is one of the solutions for workers to get a job.

Table 1. Migrant Worker Development 10 developing countries in Asia Pacific During the 2012-2018 period

\begin{tabular}{|c|c|c|c|c|c|c|c|}
\hline Negara & $\mathbf{2 0 1 2}$ & $\mathbf{2 0 1 3}$ & $\mathbf{2 0 1 4}$ & $\mathbf{2 0 1 5}$ & $\mathbf{2 0 1 6}$ & $\mathbf{2 0 1 7}$ & $\mathbf{2 0 1 8}$ \\
\hline Banglades & 550546 & 352192 & 359982 & 511581 & 711977 & 975606 & 678029 \\
\hline Indonesia & 273433 & 285882 & 292181 & 254782 & 231523 & 200006 & 194459 \\
\hline India & 745507 & 809475 & 801316 & 784050 & 520960 & 391023 & 340157 \\
\hline Nepal & 443646 & 509164 & 487800 & 403912 & 373307 & 337693 & 220653 \\
\hline Sri Lanka & 273433 & 285882 & 292181 & 254782 & 231523 & 200006 & 194459 \\
\hline Pakistan & 630490 & 612209 & 743697 & 940660 & 833738 & 490357 & 375528 \\
\hline Thailand & 104242 & 99943 & 95391 & 79671 & 89949 & 91547 & 88694 \\
\hline Viet Nam & 63046 & 73432 & 100815 & 112659 & 119232 & 128168 & 61471 \\
\hline
\end{tabular}




\begin{tabular}{|c|c|c|c|c|c|c|c|} 
Cambodia & 34804 & 22600 & 24688 & 25541 & 85576 & 96321 & 104911 \\
\hline Myanmar & 68438 & 66841 & 64610 & 95261 & 145808 & 157312 & 235404 \\
\hline
\end{tabular}

Source: ILO

From the table above, we can see the development of the number of migrant workers in several countries in Asia. Where in the last 2 years the number of migrant workers has decreased due to the moratorium on sending migrant workers, thereby reducing the number of migrant workers. Another problem that causes a decrease in the number of migrant workers is the large number of migrant workers returning because many illegal migrant workers do not have complete documents so that they are forced to return home by the destination country.

The desire of workers to migrate abroad is caused by many factors, both social and economic factors. Social factors that influence the desire for someone to become a migrant worker are the desire to get a high income. Another factor is the lack of employment opportunities due to a lack of capital, both domestic and foreign capital. Meanwhile, the role of the government as a distributor of Migrant Workers also greatly affects a person's desire to become a Migrant Worker.

With good cooperation between sending countries of migrant workers and receiving countries, it can facilitate the sending of migrant workers so that by increasing the number of sending migrant workers it can help sending countries of migrant workers reduce their unemployment rate.

Unemployment is a macroeconomic problem that affects humans directly and is the most serious. Most people losing their jobs means a decline in their standard of living and psychological stress. So it is not surprising that unemployment is a topic that is often discussed in political debates and politicians often claim that the policies they offer will help create jobs [2].

The problem of lack of employment in the country of origin of migrant workers is also influenced by the level of foreign direct investment (FDI), this is because the higher investment that enters a country will also increase employment in that country.

The total FDI entering countries of origin from the world is expected to reduce the outflow of migration from the country of origin. The results show that an increase in total FDI to a country of origin reduces outmigration [3].

The literature related to FDI and remittances shows that FDI brings many changes in the host country. The flow of FDI brings in capital, technological improvements and growth; hence, it provides employment opportunities. This lowers the incentives for migration [4].

Investment in human resources also greatly influences the intention of workers to become migrant workers, where investments that are human capital development (human capital investment) can be in the form of learning values and experiences that exist in the workforce such as increasing productivity and income. Several forms of investment in human resources can be in the form of education, health or migration. Human resources as one of the factors of production other than natural resources, capital, entrepreneurs to produce output. The higher the quality of human resources, the higher the efficiency and productivity of a country.

The economic growth of a country will also affect a person's desire to migrate abroad because a country whose economic growth continues to increase and is high has many job opportunities and has high wages so that it can increase income from labor, so that many workers go to work to other countries. a country with a high level of economic growth with the hope of getting high income.

\section{METHOD}

This study uses panel data, where the time used is the same for each variable. This study was conducted on several developing countries in Asia consisting of 10 countries, namely Bangladesh Indonesia India Nepal Sri Lanka Pakistan Thailand VietNam Cambodia Myanmar. Data for all variables in this study starting from 2012 to 2018 are sourced from the World Bank.

The specifications of this research model can be written in the form of an equation as follows:

$Y=\beta_{0}+\beta_{1} X_{1 t}+\beta_{2} X_{2}+\beta_{3} X_{3}^{2}+\beta_{4} X_{4 t}+U_{t}$.(1)

Where:

$\mathrm{Y}=$ Migrant Workers

$\mathrm{X} 1$ = Economic Growth

$\mathrm{X} 2$ = Unemployment

$\mathrm{X} 3=\mathrm{FDI}$

X4 = Human Capital

$\mathrm{U}=$ Disturbance term

$\mathrm{e}=$ Natural logarithm 
The operasional defeinitions of the variabels used in this research are:

1. Migrant Workers (Y) is a term used to describe the movement / migration of people from one place to another, with the aim of working or finding work. When migrating, they are classified as Migrant Workers. Where the vulnerable time is from 2012 to 2018. The unit used is people.

2. Economic growth (X1) is an increase in the economic activities of the community which causes an increase in the production of goods and services or an increase in national income so that it can lead to a more favorable situation during a certain period. Where the vulnerable time is from 2012 to 2018. The unit used is the dollar.

3. Unemployment (X2) is someone who is already classified in the labor force who is actively looking for work at a certain wage level, but cannot get the

\section{RESULTS AND DISCUSSION}

Based on the results of the Chow and Hausman test, the chi-square probability of 0.5806 is greater than the probability of $\alpha=0.05$, so that the random effects model is the right one to use in this study. Because in this study using the Random Effects Model, the autocorrelation and multicollinearity heterocedasticity test cannot be performed. desired job. Where the vulnerable time is from 2012 to 2018. The unit used is Percent.

4. Foreign Direct Investment (FDI) (X3) is foreign direct investment or foreign investment, where an investor in the economic sphere of a country is interested in business in the sphere of the economy of another country. This cross-border investment is usually in the form of long-term investment from overseas investors to domestic companies. So that generally foreign direct investment involves two countries at once. Where the vulnerable time is from 2012 to 2018. The unit used is the dollar.

5. The Human Development Index (HDI) (X4) is a comparative measure of life expectancy, literacy, education and living standards for all countries around the world. HDI is used to classify whether a country is a developed, developing or underdeveloped country and also to measure the effect of economic policies on the quality of life.

Table 2. Random Effect Model

\begin{tabular}{|c|c|c|c|c|}
\hline \multicolumn{3}{|l|}{ Dependent Variable: TK } & & \\
\hline \multicolumn{5}{|c|}{ Method: Panel EGLS (Cross-section random effects) } \\
\hline \multicolumn{5}{|c|}{ Date: 07/19/20 Time: 10:18 } \\
\hline \multicolumn{3}{|l|}{ Sample: 20122018} & & \\
\hline \multicolumn{3}{|l|}{ Periods included: 7} & & \\
\hline \multicolumn{3}{|c|}{ Cross-sections included: 10} & & \\
\hline \multicolumn{4}{|c|}{ Total panel (balanced) observations: 70} & \\
\hline \multicolumn{5}{|c|}{ Swamy and Arora estimator of component variances } \\
\hline Variable & Coefficient & Std. Error & t-Statistic & Prob. \\
\hline $\bar{C}$ & -115551.2 & 631011.9 & -0.183120 & 0.8553 \\
\hline LOG(PE) & 114909.1 & 37385.58 & 3.073620 & 0.0031 \\
\hline PENGANGGURAN & 62738.72 & 20994.86 & 2.988290 & 0.0040 \\
\hline LOG(FDI) & -80171.75 & 25070.10 & -3.197903 & 0.0021 \\
\hline HI & -1509218 & 389205.6 & -3.877690 & 0.0002 \\
\hline & & & & \\
\hline
\end{tabular}




\begin{tabular}{|c|c|c|c|c|}
\hline & \multicolumn{2}{|c|}{ Effects Specification } & \multirow[b]{2}{*}{ S.D. } & \multirow[b]{2}{*}{ Rho } \\
\hline & & & & \\
\hline & & & & \\
\hline \multicolumn{3}{|l|}{ Cross-section random } & 79538.60 & 0.2890 \\
\hline \multicolumn{3}{|l|}{ Idiosyncratic random } & 124746.5 & 0.7110 \\
\hline & \multirow{2}{*}{\multicolumn{2}{|c|}{ Weighted Statistics }} & & \\
\hline & & & & \\
\hline R-squared & 0.453249 & \multicolumn{2}{|c|}{ Mean dependent var } & 1597982 \\
\hline Adjusted R-squared & 0.419603 & \multicolumn{2}{|c|}{ S.D. dependent var } & 162308.4 \\
\hline S.E. of regression & 123652.7 & \multicolumn{2}{|c|}{ Sum squared resid } & $9.94 \mathrm{E}+11$ \\
\hline F-statistic & 13.47104 & \multicolumn{2}{|c|}{ Durbin-Watson stat } & 1.116400 \\
\hline \multirow[t]{2}{*}{ Prob(F-statistic) } & 0.000000 & & & \\
\hline & \multicolumn{2}{|c|}{ Unweighted Statistics } & & \\
\hline & & \multirow{2}{*}{\multicolumn{2}{|c|}{ Mean dependent var }} & \\
\hline R-squared & 0.722233 & & & 313373.7 \\
\hline Sum squared resid & $1.24 \mathrm{E}+12$ & \multicolumn{2}{|c|}{ Durbin-Watson stat } & 0.983371 \\
\hline
\end{tabular}

Sources: Data Proceed with Eviews 8, 2020

Based on the table of secondary data processing results using Eviews 8, the panel regression equation is obtained as follows:

Yit $=-115551.2+114909.1 \mathrm{X}_{1 \mathrm{it}}+62738.72 \mathrm{X}_{2 \mathrm{it}^{+}}{ }^{-}$ $80171.75 X_{\text {ait }}+1509218 X_{4 i t}$

The F-statistic probability value is 0.000000 . This value is smaller than the error rate $\alpha=0.05$, which means that the independent variables, namely Economic Growth, Unemployment, FDI and the Human Development Index have a significant effect on the dependent variable namely Migrant Workers.

Based on the results of the research conducted, it shows that Economic Growth (X1) has a positive and significant effect on Migrant Workers (Y) in 10 developing countries in Asia Pacific with a regression coefficient of 114909.1. This means that if Economic Growth increases by 1 unit, there will be an increase in Migrant Workers in 10 developing countries in Asia Pacific by 114909.1 . F. Mete (2004) analyzed the relationship between migration and GDP per capita with the aid of the Granger causality test using data from 1981 to 2001 in Finland. In his analysis, he concluded that there is no statistically significant causality between migration and GDP per capita. According to research by E. Boubtane et al., (2011) to analyze the relationship between migration and economic growth with the help of panel causality tests in 22 selected OECD countries. In their analysis, they conclude that migration in Portugal is the cause of negative migration, growth affects international migration positively. The estimation results are relevant to the research of [5].

Based on the results of the equation research shows that unemployment (X2) has a positive effect on migrant workers $(\mathrm{Y})$ in 10 developing countries in Asia Pacific with a regression coefficient of 62738.72. This means that if unemployment increases by 1 unit, there will be an increase in Migrant Workers in 10 developing countries in Asia Pacific by 62738.72. [1] try to examine socio-economic factors by referring to the Borjas migration theory which sees migration as a result of a country's population explosion, differences in income between countries, political conditions, and prevailing immigration policies. As a result, population density, per capita income, adult literacy, political instability, and unemployment significantly influence migration. The estimation results are relevant to the research of [6] [7].

Based on the results of the equation research, it shows FDI (X3) has a positive effect on Migrant Workers (Y) in 10 developing countries in Asia Pacific with a regression coefficient of -80171.75 . This means that if FDI increases by 1 unit, it will reduce Migrant Workers in 10 developing countries in Asia Pacific by 80171.75. [8] argues that FDI reduces migration incentives in the short term providing prospective migrants with employment opportunities and in the long term by increasing growth and reducing poverty. The results of this study are in line with [4] theory. Literature relating to FDI and remittances shows that 
FDI brings many changes in the host country. The flow of FDI brings in capital, technological improvements and growth; hence, it provides employment opportunities. This lowers the incentives for migration. The estimation results are relevant to the research of [9] [10].

Based on the results of the equation research shows the Human Development Index (X4) has a negative effect on Migrant Workers (Y) in 10 developing countries in Asia Pacific with a regression coefficient of -1509218. This means that if the Human Development Index increases by 1 unit, it will reduce Migrant Workers in 10 developing countries in Asia Pacific by 1509218. The results of this study are in line with [11]. Human resource investment is a cost that must be sacrificed in the form of money, time, and opportunities to shape better human capital in the future. Meanwhile, human capital (human capital) is a term often used by economists for education, health, and other human capacities that can increase productivity if these things are increased. High productivity will spur a higher aggregate output growth rate. The estimation results are relevant to the research of [12].

\section{CONCLUSION}

From the above discussion we can conclude

1. Based on the results of research conducted, it shows that Economic Growth (X1) has a positive and significant effect on Migrant Workers (Y) in 10 developing countries in Asia Pacific.

2. Based on the results of the equation research shows unemployment (X2) has a positive effect on Migrant Workers (Y) in 10 developing countries in Asia Pacific.

3. Based on the results of the equation research, it shows that FDI (X3) has a positive effect on Migrant Workers (Y) in 10 developing countries in Asia Pacific.

4. Based on the results of the equation research shows the Human Development Index (X4) has a positive effect on Migrant Workers (Y) in 10 developing countries in Asia Pacific.

\section{REFERENCES}

[1] F. W. Agbola and B. A. Angelito, "An empirical analysis of international labour migration in the Philippines," Econ. Syst., vol. 3, no. 4, pp. 386-396, 2010.

[2] G. Mankiw, Pengantar Ekonomi Makro. Jakarta: Salemba Empat, 2006.

[3] C.-S. Kim and M. S. Park, "Trade, Foreign Direct Investment and International Flow of Labor: OECD Countries," J. Int. AREA Stud., vol. 19, no. 2, pp. 112, 2012.

[4] H. Sultana and A. Fatima, "Factors influencing migration of female workers: a case of Bangladesh," IZA J. Dev. Migr., vol. 7, no. 4, pp. 1-17, 2017.

[5] S. Z. Kemu and Et.al, "Pengaruh Pertumbuhan Ekonomi (PDB) Terhadap Penciptaan Kesempatan Kerja," Kaji. Ekon. dan Keuang., vol. 9, no. 3, 2005.

[6] B. Rabe and T. Mark, Differences in Opportunities? Wage, Unemployment and House-Price Effects on Migration. Institute for Social and Economic Research University of Essex, 2010.

[7] A. Zaiceva, "Post-enlargement emigration and new EU members' labor markets," IZA World Labor, vol. 40, 2014.

[8] H. Jayet and L. Marchal, Migration and FDI: Reconciling the standard trade theory with empirical evidence, vol. 2039. Kiel, 2016.

[9] H. De Haas, "Turning the Tide? Why Development Will Not Stop Migration,” Dev. Change, vol. 38, no. 5, pp. 819-841, 2007.

[10] E. D’Agosto, N. Solferino, and G. Tria, "Does FDI affect migration flows? The role of human capital," Migr. Lett., vol. 10, no. 3, pp. 359-368, 2013.

[11] M. . . Todaro and S. . . Smith, Pembangunan Ekonomi, 9th ed. Jakarta: Erlangga, 2006.

[12] R. C. Connel, Contemporary Labor Economics. McGraw-Hill: University of Nebraska, 1999. 